\title{
Assessing Authenticity of Selected Cultural Heritage Sites of Paoay, Ilocos Norte: A Study on Enhancing Visitors' Experience
}

\author{
Rushiell May Oasay ${ }^{1}$, Ma. Cristina Williams, Ph. D. ${ }^{2}$ \\ University of Perpetual Help System DALTA, Calamba Laguna ${ }^{1}$, \\ Centro Escolar University, Manila² \\ \{rushiellmay@gmail.com¹,mrwilliams@ceu.edu.ph $\left.{ }^{2}\right\}$
}

\begin{abstract}
Cultural tourism is one of the developing sectors in the tourism industry. As tourism is experiencing significant changes, expectation is set constantly in terms of the quality of the experience pursued by tourists. This study examined the relationship between authenticity and visitors' experience. Mixed method research was used and the hypothesis was tested using Pearson $r$ correlation. Questionnaire and interview were the instruments of the study. The study suggests that there is a significant relationship between authenticity and visitors' experience, $\mathrm{r}(385)=.89, \mathrm{p}>.01$. The existing tourism plans and programs in the municipality of Paoay, Ilocos Norte includes marketing programs, economic, physical infrastructure and socio-cultural plans and programs for both the visitors and local people. Visitors' Experience Enhancement Program (VEEP) was developed based on the results of the study to help improve the quality of visitors' experiences in a cultural heritage site.
\end{abstract}

Keywords: authenticity in tourism, cultural heritage, visitor experience, Paoay

\section{Introduction}

Cultural tourism is one of the key activities [1], and will be the economic sector with the most rapid development of the tourism industry [2], [3], [4]. There has been a movement towards increased specialization among visitors [4], and as studies show, cultural heritage is one of the determinants of travel [5], [6], [7], [8], [9], [10], [11]. Bordoni [12] also claimed that tourism industry is already fast-paced and experiencing significant changes and transformations, and expectation is being set constantly in terms of the quality of the experience pursued.

Cultural tourism signifies the denunciation of present-day mass culture a pursuit for enhanced or diverse means of life. This form of travel has become a practice of therapy and self-actualization for many individuals. Modern visitors searching for exotic destinations and experiences believe it can help their lives change [13]. Even if in a short amount of time visitors preferred to experience the old ways of life [14], they continued to collect tourist attractions or places of distinguishing and parallelizing erratic stages during their life's progression [7]. Study revealed that, in a post-modern consumption environment, tourism destinations expected to give or incorporate an uncommon attribute that goes beyond usual 
tourist attractions as tourists have become more demanding [4] and self-governing, and have been able to select and evaluate cultural activities according to the level of available information [8]. This cannot however be denied that there are various forms of visitors. Many visitors happy with fake sites and practices; others want real sites while others may prefer mediated types of it with touches of reality [15].

In appreciating cultural heritage, its authenticity is also appraised because cultural tourists often expect historical reality [16]. However, authenticity has always been the focus of discussion in tourism research over the years [17], particularly on culture and heritage [18], [15], [19]. Because of its ambiguous nature it has no standard definition and no set of parameters to define, hence, it varies in meaning [18]. Tourism's definition of authenticity evolved from genuineness in nature to the way people viewed their feelings and perceptions [16]. It is often produced, modified and commercialized only to suit the needs of the visitors [16]. Several studies also show that authenticity tends to be a remarkable characteristic of cultural heritage destinations [20], [21], while others claim that it is a qualification attributed to identity or culture and a factor in the appreciation of their experiences by visitors and performers [22] and that [23] have reported that authenticity is connected to visitor satisfaction and loyalty at cultural heritage sites.

Despite the varied perspective about authenticity, the researcher focused the study on the concept of authenticity specifically objective authenticity - related to the model, or the actual [24]; performative authenticity - demonstrated in (from within) view of the body at play, at risk, invested, and intensified [25]; and existential authenticity - relates to a state of actuality [24]. This is to further analyze the interpretations of the visitors on authenticity.

In the Philippines, tourism is one of its economical drivers. Cultural tourism sector plays an important role as it contributes a big portion in the success of its tourism industry. The country houses many cultural heritage attractions from century old churches, historical places, to celebration of festivals and other intangible cultural heritages. The Philippines has been blessed with manmade and natural attractions. As a matter of fact, there are currently six (6) UNESCO World Heritage Sites (WHS) in the Philippines. The properties inscribed on the World Heritage List for Natural are: Mount Hamiguitan Range Wildlife Sanctuary (2014), Puerto-Princesa Subterranean River National Park (1999), Tubbataha Reefs Natural Park (1993, 2009); and Cultural: Baroque Churches of the Philippines (1993), Historic City of Vigan (1999), Rice Terraces of the Philippine Cordilleras (1995).

The Philippines has four Baroque Churches. These four churches, of which the Spaniards constructed the first in the late 16th century are San Agustin Church, Intramuros, Manila; Church of La Nuestra Señora de la Asuncion, Santa Maria, Ilocos Sur; Church of San Agustin, Paoay, Ilocos Norte; and Church of Santo Tomas de Villanueva, Miag-ao, Iloilo. Their unique architectural style is a reinterpretation of European Baroque by Chinese and Philippine craftsmen.

Among these four Baroque Churches of the Philippines, the Church of San Agustin in Paoay, Ilocos Norte was pointed out in the UNESCO listing as the most outstanding example of the Earthquake proof Baroque Architectural Style (UNESCO). The most striking feature of the church is the formation of buttresses which only emerge vertically from the sides to strengthen the walls against earthquake damage. This is the most extensive support in any church in the Philippines. Fourteen S-shaped buttresses nearly rise from the ground to the roof line at rhythmic cadence. Each buttress has a triumphant pyramidal roof [26].

The province of Ilocos Norte, where San Agustin Church (Paoay Church) is located, is very rich in cultural and natural attractions, as a support to this, the province was tagged by Asiatravel.com, Consulate of People's Rebulic of China in Laoag and Ilocos Region among 
others as "The Best of Culture and Nature". The province houses natural attractions like the Kapurpurawan Rock Formation, Pagudpud Beach, Kabigan Falls, Paoay Lake and the Sand Dunes; and cultural attractions like the Cape Bojeador Lighthouse, Juan Luna Shrine, St. William Cathedral and Sinking Bell Tower, Museo Ilocos Norte, Malacañang of the North and San Agustin Church.

With the desire to upkeep the tourism industry in the province, they used the tagline "Paoay Kumakaway" as its marketing strategy to promote domestic tourism [27], because the strong point of the province is culture and Paoay represents the province well. It is the most strategic town in the province, it is beside Laoag, Batac, Currimao, San Nicolas and it is a five-minute travel from the airport [27]. The Paoay Kumakaway campaign was used because Paoay specifically the Paoay Church was the focus and the bestselling point of the province in terms of tourism [27].

Aside from the San Agustin Church, there are lot of thing to do and see in Paoay, and these are Paoay Sand Dunes, Paoay Lake, Malacañang of the North, Presidencia, Aglipay Church, The Old Convent, Paoay Central's Gabaldon, Paoay Old Bridges, Ancestral Houses and Water Wells, intangible heritage like Inabel, Cornick, Dudol, Tumba Festival, Guling-guling Festival and other things of a similar kind. Among the attractions mentioned, three of these where included in the top 10 things to do in in Ilocos Norte Province by TripAdvisor [28], and from these three, only two were under the category of culture, and these were the San Agustin Chuch being the first, and Malacañang of the North on the tenth.

The San Agustin Church (Paoay Church) is one of the most visited cultural heritage attractions in the province of Ilocos Norte and is part of the three (3) Marcos Heritage Trail destinations including the Malacanang of the North (Paoay) and Marcos Museum (Batac City). This was identified by the Ilocos Norte Tourism Office (INTO) to promote the cultural heritage attractions of the southern area of the province [29]. Next to San Agustin Church which recorded a 54,015 visitors on Holy Week of 2017 alone is the Malacanang of the North with a 16,483 tourists on the same duration [30].

Malacañang of the North, also known as Malacañang ti Amianan, was a birthday gift from the former Philippine First Lady, Imelda Marcos, to the sixtieth birthday of her husband. It is among the family's assets which the Philippine government sequestered when President Marcos was removed from power. It was eventually returned back to the care of the Provincial Government of Ilocos Norte after 20 years under government control. Following the Governor's restorations and improvements, it was opened to the public as a museum on 1 January 2011 [31]. This majestic house with its sprawling expanse is intricately built and resembled a Bahay na Bato of the 19th century with a combination of Spanish and Ilocano architecture [31]. The Malacañang of the North is one of the three Marcos Heritage Trail destinations in Ilocos Norte [29]. The province of Ilocos Norte recorded a total of 2.03 million tourist arrivals in 2016 and these two (2) cultural heritages sites were factors of the increase (INTO).

With this huge number of tourist arrivals in the province, the Ilocos Norte Tourism Office and the Municipal Tourism Office (MTO) of Paoay continue to provide plans and programs for the industry and it focuses on Marketing program which highlights Domestic Tourism; Economic plans and programs that will invite investments and create jobs for local people; Physical Infrastructure plans and programs that focuses on renovation of old, construction of new and maintenance of existing buildings; and socio-cultural plans and programs that will provide new activities for visitors and enhance the awareness of the local people.

However, despite of the plans, programs and efforts of the INTO and MTO of Paoay in providing services to visitors, they still received comments, suggestions and complaints from 
them. Thus, the objective of the study is to assess the perception of the respondents on the authenticity of the Cultural Heritage Sites of Paoay, Ilocos Norte specifically, Paoay Church and Malacañang of the North, examine their actual experiences using the Experiential Marketing Theory of Schmitt [32]. The Schmitt's theory contends that experience can be in sensory (includes the senses of hearing, vision, smell, taste and touch), affective (appeals to customers' inner feelings and emotions), creative-cognitive (appeals to the intellect with the objective of creating cognitive, problem-solving experiences that engage customers creatively), physical (enriches customers' lives by targeting their physical experiences, showing them alternative ways of doing things), and social-identity (contains aspects of sense, feel, think and act). The study also aimed to find the relationship of authenticity and visitor's experience in a cultural heritage site and how can the experience of the visitors to Paoay, Ilocos Norte be enhanced?

The study will be beneficial to the tourist destination especially cultural heritage sites, considering that this will give them the idea on how to showcase cultural heritage attractions tailored-fit to the perception of authenticity of visitors that can eventually lead to the enhancement of their experience. For the Department of Tourism, this study can be used as an empirical basis in implementing tourism experiential programs and promoting only in the Philippines' authentic cultural heritage destinations that will be beneficial to both the local community and the visitors. For the tour operators and travel intermediaries, they can use this study in gaining deeper understanding of their customers' experiences thus, can help them improve their tour packages by including activities that can enhance specific aspects of visitors' experience of the cultural heritage sites. For the local community of Paoay, Ilocos Norte, this study can give them an insight on how they can be greatly part in making or breaking the visitor's experience. For the future researchers, they can use this study in assessing authenticity of a site and the experiences of visitors in a cultural heritage destination in the future.

\section{Methodology}

Mixed methods research was used in this study. The respondents of the study were visitors visiting any of the two cultural heritage sites of Paoay, Ilocos Norte (San Agustin Church and the Malacañang of the North). The study acquired and employed the responses of three hundred eighty-five (385) respondents in order to draw a reliable information on the study. The sample size was computed using the Raosoft, an online sample size calculator, applying a $95 \%$ confidence level and a 5\% margin of error. Simple random sampling was used in the study. Questionnaire was handed over to both local and foreign tourists as respondents individually.

The questionnaire that was used in the study is composed of three parts: Part I comprises the socio-demographic profile of the respondents; Part II contains nineteen (19) self-made questions that helped answer the type and level of authenticity of the respondents. Part III of the instrument includes twenty-three (23) self-made questions pertaining to the experiences of the visitors in the cultural heritage site. A pilot test was conducted to check the reliability of the questionnaire. The result of the Cronbach's alpha was .98 , which means very high and that the research instrument is reliable.

Another instrument was the interview. The researcher was able to conduct an interview with the officer-in-charge of the Tourism Office of Paoay, Mr. Allan Saddam and one of the Tourism Operations Officer of Ilocos Norte Tourism Office, Mr. A-Xavier Ruiz regarding the 
previous and existing tourism plans and programs in the municipality and province. Descriptive statistics was used to address the level of authenticity and experiences of the respondents on the Cultural Heritage Sites of Paoay, Ilocos Norte. To present the scores of the perceived authenticity and experiences of the respondents, the mean and standards deviation was used. To see the significant relationship of the variables, Pearson correlation coefficient was used.

\section{Results and Discussion}

\subsection{Sociodemographic Characteristics of the Respondents}

Table 1. Demographic Profile of the Respondents.

\begin{tabular}{lccc}
\hline Categories & $\begin{array}{c}\text { \% of frequency } \\
\mathbf{N}=\mathbf{3 8 5}\end{array}$ & $\begin{array}{c}\text { San Agustin Church } \\
\mathbf{n = 2 0 0}\end{array}$ & $\begin{array}{c}\text { Malacañang of the North } \\
\mathbf{n}=\mathbf{1 8 5}\end{array}$ \\
\hline Gender & & & \\
Male & 41.8 & 38.5 & 45.4 \\
Female & 57.7 & 60.5 & 54.6 \\
Others & .5 & 1.0 & 0 \\
Marital Status & & & \\
$\quad$ Single & 71.4 & 78.5 & 63.8 \\
Married & 27.5 & 21.0 & 34.6 \\
Widow & 1.0 & .5 & 1.6 \\
Educational Attainment & & & \\
Elementary & 1.6 & 2.0 & 1.1 \\
High School & 20.0 & 25.0 & 4.6 \\
Vocational & 2.9 & 1.5 & 4.3 \\
College & 66.2 & 65.0 & 12.4 \\
Post Graduate & 9.4 & 6.5 & \\
Age & & & 29.7 \\
8-21 & 34.0 & 38.0 & 35.1 \\
22-35 & 35.8 & 36.5 & 14.6 \\
36-49 & 13.2 & 12.0 & 5.9 \\
50-63 & 4.2 & 2.5 & 3.8 \\
64-77 & 2.1 & .5 & 10.8 \\
Did not specify & 10.6 & 10.5 & \\
\hline
\end{tabular}

Table 1 shows the demographic characteristics of the respondents. As reported, $57.7 \%$ were female, $41.8 \%$ of the visitors were male and $.5 \%$ were others. About $71.4 \%$ of the visitors were. Majority of visitors (66.2\%) reported that they were educated to college level, while $20 \%$ were high school level and $9.4 \%$ reported they had post graduate education. Visitors were predominantly between the ages 8 and 35 , with $35.8 \%$ in the $22-35$ age group and $34 \%$ in the $8-21$ age group.

For the San Agustin Church respondents, $60.5 \%$ of them were female, $38.5 \%$ were male. Majority were single with $78.5 \%$. Predominantly, $65 \%$ reported that they were educated to college level. For Malacañang of the North, $54.6 \%$ of the respondents were female, $45.4 \%$ were male. Majority were single with $63.8 \%$. Predominantly, $67 \%$ reported that they were educated to college level.

\subsection{Perceived Authenticity of Cultural Heritage Sites in Paoay, Ilocos Norte}


Tables 2 to 4 present the results regarding the authenticity of the Cultural Heritage Sites of Paoay, Ilocos Norte in terms of Objective Authenticity, Performative Authenticity and Existential Authenticity.

Table 2. Objective Authenticity of Cultural Heritage Sites of Paoay, Ilocos Norte.

\begin{tabular}{|c|c|c|c|c|c|c|}
\hline \multirow{2}{*}{ Objective Authenticity } & \multicolumn{3}{|c|}{$\begin{array}{c}\text { San Agustin Church } \\
\mathbf{n}=\mathbf{2 0 0}\end{array}$} & \multicolumn{3}{|c|}{$\begin{array}{l}\text { Malacañang of the North } \\
n=185\end{array}$} \\
\hline & Mean & SD & VI & Mean & SD & VI \\
\hline $\begin{array}{l}\text { The historical building at the cultural heritage } \\
\text { sites gave me a feel of life during that time. }\end{array}$ & 4.29 & .80 & Strongly Agree & 4.02 & 1.00 & Agree \\
\hline $\begin{array}{l}\text { The structures and amenities around the site } \\
\text { gave me a feel of life during that time. }\end{array}$ & 4.20 & .87 & Agree & 3.95 & 1.00 & Agree \\
\hline $\begin{array}{l}\text { The site is a representative of the whole } \\
\text { Ilocos Region. }\end{array}$ & 4.08 & .97 & Agree & 3.69 & 1.15 & Agree \\
\hline $\begin{array}{l}\text { The features of the interior showcase the } \\
\text { uniqueness of their time period. }\end{array}$ & 4.26 & .91 & Strongly Agree & 3.98 & 1.03 & Agree \\
\hline $\begin{array}{l}\text { The design of the cultural heritage site } \\
\text { represents the architectural style of that } \\
\text { period }\end{array}$ & 4.41 & .85 & Strongly Agree & 4.11 & .93 & Agree \\
\hline $\begin{array}{l}\text { The structures around the cultural heritage } \\
\text { site represents the architectural style of that } \\
\text { period. }\end{array}$ & 4.35 & .85 & Strongly Agree & 4.02 & .93 & Agree \\
\hline $\begin{array}{l}\text { The local surroundings of the cultural } \\
\text { heritage site still appears to be in its original } \\
\text { condition. }\end{array}$ & 4.03 & .94 & Agree & 3.69 & 1.01 & Agree \\
\hline Overall Mean & 4.23 & & Strongly Agree & & & Agree \\
\hline
\end{tabular}

Table 2 shows that among the items of objective authenticity, the design of the cultural heritage site represents the architectural style of that period rated highest with a mean score of 4.41 and standard deviation of .85 for San Agustin Church and 4.11 with a standard deviation of .93 for Malacañang of the North.Visitors perceive the two cultural heritage sites as objectively authentic. The local surroundings of the cultural heritage site still appear to be in its original condition rated the lowest for the San Agustin Church with a mean score of 4.03. Visitors may had seen other parts of the church that was been renovated and assumed that it does not appear as original as before though their rating is still agree.

In the case of Malacañang of the North, the site is a representative of the whole Ilocos Region and the local surroundings of the cultural heritage site still appears to be in its original condition rated the lowest with a mean score of 3.69. An overall mean of 4.23 and 3.92 was computed for San Agustin Church and Malacañang of the North respectively, which means, respondents agree that objective authenticity exist in both sites.

Most of the time, visitors perceived the destination they are visiting, in this case, the cultural heritage sites objectively. It is important to them that the site they are visiting is still the same as it is in the old days because in that way, visitors of cultural heritage sites can experience and immerse their selves on the practices and old life of the past. This has been supported by the study of Chhabra, Healy, \& Sills [14] that even in a short period of time, tourist wanted to experience the old ways of life.

Table 3. Performative Authenticity of Cultural Heritage Sites of Paoay, Ilocos Norte.

\begin{tabular}{llllllll}
\hline \multirow{2}{*}{ Performative Authenticity } & \multicolumn{3}{c}{ San Agustin Church $\mathbf{n = 2 0 0}$} & \multicolumn{3}{c}{ Malacañang of the North n=185 } \\
\cline { 2 - 8 } & \multicolumn{2}{c}{ Mean } & SD & VI & Mean & SD & VI \\
\hline $\begin{array}{l}\text { The features inside the cultural heritage } \\
\text { site allow me to relive the period. }\end{array}$ & 4.03 & .89 & Agree & 3.81 & 1.00 & Agree \\
There are interactive features at the cultural & 3.93 & .99 & Agree & 3.65 & 1.09 & Agree \\
\hline
\end{tabular}




\begin{tabular}{|c|c|c|c|c|c|c|}
\hline \multirow{2}{*}{ Performative Authenticity } & \multicolumn{3}{|c|}{ San Agustin Church $\mathbf{n}=\mathbf{2 0 0}$} & \multicolumn{3}{|c|}{ Malacañang of the North $n=185$} \\
\hline & Mean & SD & VI & Mean & SD & VI \\
\hline $\begin{array}{l}\text { heritage site that allow me to relive the } \\
\text { period. }\end{array}$ & & & & & & \\
\hline $\begin{array}{l}\text { The locals of the cultural heritage site } \\
\text { displayed their usual trait of } \\
\text { industriousness and frugality. }\end{array}$ & 4.01 & .97 & Agree & 3.66 & .98 & Agree \\
\hline $\begin{array}{l}\text { I learned many interesting facts about the } \\
\text { site from the local people. } \\
\text { The cultural heritage site clearly portrayed } \\
\text { the Spanish cultures. (San Agustin Church) }\end{array}$ & 3.84 & 1.09 & Agree & 3.61 & 1.12 & Agree \\
\hline $\begin{array}{l}\text { The cultural heritage site clearly portrayed } \\
\text { the Filipino cultures. (Malacañang of the } \\
\text { North) }\end{array}$ & 4.20 & .91 & Agree & 3.84 & 1.06 & Agree \\
\hline Overall Mean & 4.00 & & Agree & 3.71 & & Agree \\
\hline
\end{tabular}

Table 3 shows that most of the respondents agree that the San Agustin Church clearly portrayed the Spanish cultures with the highest mean score of 4.20 and standard deviation of .91 and the Malacañang of the North clearly portrayed the Filipino cultures with the highest mean score of 3.84 with standard deviation of 1.06 which means answers of the respondents were very scattered. The statement I learned many interesting facts about the site from the local people receives the lowest mean for the both cultural heritage sites. This means that there was no much interaction with the local people while the visitors are inside the cultural heritage sites. An overall mean of 4.00 and 3.71 was computed for San Agustin Church and Malacañang of the North respectively, which means, respondents agree that performative authenticity exist in both sites.

Aside from the original structures, another way of experiencing authenticity is thru the interaction with the local people. Visitors will have a better experience if they were able to saw, experienced what the locals do, or talked and had an interaction with the locals. By doing so, in one way or another, they experienced the culture of the place. As been stated in the study of Knudsen \& Waade [25] that authenticity is 'something which people can do and a feeling which is experienced'. The results of this study may help management of cultural heritage sites of various ways on how to present authenticity of the site to the visitors as part of the tour experience.

Table 4. Existential Authenticity of Cultural Heritage Sites of Paoay, Ilocos Norte.

\begin{tabular}{|c|c|c|c|c|c|c|}
\hline \multirow{2}{*}{ Existential Authenticity } & \multicolumn{3}{|c|}{ San Agustin Church $n=200$} & \multicolumn{2}{|c|}{ Malacañang of the North } & \multirow{2}{*}{$\frac{n=185}{V I}$} \\
\hline & Mean & SD & VI & Mean & SD & \\
\hline $\begin{array}{l}\text { I appreciated the authenticity of the } \\
\text { local natural surroundings in the } \\
\text { cultural heritage site. }\end{array}$ & 4.24 & .88 & $\begin{array}{l}\text { Strongly } \\
\text { Agree }\end{array}$ & 3.99 & .99 & Agree \\
\hline $\begin{array}{l}\text { I experienced the culture and } \\
\text { personalities of the Philippine } \\
\text { history while inside the cultural } \\
\text { heritage site. }\end{array}$ & 4.12 & .88 & Agree & 3.88 & .97 & Agree \\
\hline $\begin{array}{l}\text { I was able to connect with human } \\
\text { history and civilization at the site. } \\
\text { I enjoyed the exceptional }\end{array}$ & 4.02 & .94 & Agree & 3.84 & 1.01 & Agree \\
\hline $\begin{array}{l}\text { divine/mortal experience while } \\
\text { inside the site. }\end{array}$ & 4.07 & .93 & Agree & 3.69 & 1.10 & Agree \\
\hline $\begin{array}{l}\text { I sensed the quiet and serene } \\
\text { ambiance during the visit at the } \\
\text { site. }\end{array}$ & 4.13 & .96 & Agree & 3.65 & 1.19 & Agree \\
\hline $\begin{array}{l}\text { I felt the authenticity of the } \\
\text { cultural heritage site thru the well- }\end{array}$ & 4.02 & 1.03 & Agree & 3.64 & 1.14 & Agree \\
\hline
\end{tabular}




\begin{tabular}{l}
\hline \multirow{2}{*}{ Existential Authenticity } \\
\cline { 2 - 7 }
\end{tabular}

Table 4 shows that the most of the respondents agreed to both cultural heritage sites where in they appreciated the authenticity of the local natural surroundings in the cultural heritage site. Having the highest mean score of 4.24, standard deviation of .88 for San Agustin Church and mean score of 3.99 and statdard deviation of .99 for Malacañang of the North, the answers of the respondents based on the standard deviation is very far from each other. The statement, I was able to connect with human history and civilization at the site received the lowest rate in San Agustin Church with a mean score of 4.02. I felt the authenticity of the cultural heritage site thru the well-ordered activities/tours conducted received the lowest mean for Malacañang of the North with a mean score of 3.64. This is due to no other activities inside the museum but to roam around and take pictures only. An overall mean of 4.10 and 3.77 was computed for San Agustin Church and Malacañang of the North respectively, which means, respondents agree that existential authenticity exist in both sites.

As with the study of MacCannell [33], he assumes that tourists hope to experience authenticity in an encounter with authentic sites, objects or events. He argued that tourists' quest for authenticity to escape from their day-to-day mundane life. It was also stated in the study of Expedia [34] about millennials that authenticity is ultimately whatever which supports their perceptions of value: cultural appreciation and "living like a local"; independence and finding those hidden gems; originality and balancing the iconic with those experiences that are more off the beaten track.

\subsection{Visitors' Experiences at the Cultural Heritage Sites in Paoay, Ilocos Norte}

Tables 5 to 9 show the results regarding the experiences of the respondents on the Cultural Heritage Sites of Paoay, Ilocos Norte in terms of Sensory Experiences (Sense), Affective Experiences (Feel), Creative Cognitive Experiences (Think), Physical Experiences (Act), and Social-identity Experiences (Relate).

Table 5 shows that among the items for sensory experiences, most of the respondents agreed that the original materials used in building the San Agustin Church and Malacañang of the North is evidently seen on its foundations, walls and floors receiving a mean score of 4.17 with standard deviation of .88 and 3.90 with standard deviation of 1.08 respectively. The respondents rated the item there is a distinct smell inside the cultural heritage site lowest to both sites. This means that during their visit to the cultural heritage sites, their sense of sight was the most engaged among the other senses. An overall mean of 4.00 and 3.62 was computed for San Agustin Church and Malacañang of the North, which means, respondents agree that they engaged their senses for their experience in the cultural heritage site.

Table 5. Sensory Experiences (Sense) at the Cultural Heritage Sites.

\begin{tabular}{lllllllll}
\hline \multirow{2}{*}{ Sensory Experiences (Sense) } & & \multicolumn{3}{c}{ San Agustin Church n=200 } & \multicolumn{3}{c}{ Malacañang of the North n=185 } \\
\cline { 2 - 8 } & Mean & SD & VI & Mean & SD & VI \\
\hline $\begin{array}{l}\text { The original materials used in } \\
\text { building the cultural heritage site is } \\
\text { evidently seen by the visitors on its }\end{array}$ & 4.17 & .88 & Agree & 3.90 & 1.08 & Agree \\
\hline
\end{tabular}




\begin{tabular}{|c|c|c|c|c|c|c|}
\hline \multirow{2}{*}{ Sensory Experiences (Sense) } & \multicolumn{3}{|c|}{ San Agustin Church $\mathbf{n}=\mathbf{2 0 0}$} & \multicolumn{3}{|c|}{ Malacañang of the North $n=185$} \\
\hline & Mean & SD & VI & Mean & SD & VI \\
\hline foundations, walls and floors. & & & & & & \\
\hline $\begin{array}{l}\text { There is a distinct smell inside the } \\
\text { cultural heritage site. }\end{array}$ & 3.56 & 1.15 & Agree & 3.37 & 1.21 & Somewhat Agree \\
\hline $\begin{array}{l}\text { The local restaurants within the } \\
\text { vicinity of the cultural heritage sites } \\
\text { offers/serves specialty Ilocano dishes }\end{array}$ & 4.08 & .91 & Agree & 3.51 & 1.13 & Agree \\
\hline $\begin{array}{l}\text { Touching the furnishing and decors of } \\
\text { the cultural heritage site enriched my } \\
\text { experience. }\end{array}$ & 4.03 & .92 & Agree & 3.57 & 1.06 & Agree \\
\hline $\begin{array}{l}\text { The sanctity and serenity of the } \\
\text { cultural heritage site can be felt. (San } \\
\text { Agustin Church) } \\
\text { The vibrancy and bustle of life is } \\
\text { evident at the site. (Malacañang of the } \\
\text { North) }\end{array}$ & 4.15 & .88 & Agree & 3.75 & .99 & Agree \\
\hline Overall Mean & 4.00 & & Agree & 3.62 & & Agree \\
\hline
\end{tabular}

The result of this study implies that visitors tend to use their senses when they are visiting a cultural heritage site. They use their sense of sight most of the time, since most of the attractions are in visuals. This was been supported by Musa et al. [35] that in their study about exploring visitors' experience in the case of Zoo Negara, Kuala Lumpur and within the sense dimension, expectedly, sight was the most frequently expressed. This also implies that cultural heritage sites and other attractions focuses more on the visual aspect of the attractions and fails most of the time to give and offer experiences that will also engage the other sense of the visitors.

Table 6 shows that most of the respondents agreed that visiting the cultural heritage site gave them a positive experience outside their routine which receives the highest rating among the other affective experiences with a mean score of 4.22 with standard deviation of .84 and 3.89 and a standard deviation of 99 for San Agustin Church and Malacanañang of the North respectively. This explains that the respondents experienced a positive mood like strong emotions of joy and pride while inside the cultural heritage site. An overall mean of 4.13 and 3.80 was computed for San Agustin Church and Malacañang of the North respectively, which means, respondents agree that affective experience can be felt in both cultural heritage sites.

Table 6. Affective Experiences (Feel) at the Cultural Heritage Sites.

\begin{tabular}{|c|c|c|c|c|c|c|}
\hline \multirow{2}{*}{ Affective Experiences (Feel) } & \multicolumn{3}{|c|}{ San Agustin Church $\mathbf{n}=\mathbf{2 0 0}$} & \multicolumn{3}{|c|}{ Malacañang of the North $n=185$} \\
\hline & Mean & SD & VI & Mean & SD & VI \\
\hline $\begin{array}{l}\text { The safety and security of the site } \\
\text { during its period can be felt. }\end{array}$ & 4.06 & .86 & Agree & 3.83 & .98 & Agree \\
\hline $\begin{array}{l}\text { Visiting the cultural heritage site gave } \\
\text { me a positive experience outside my } \\
\text { routine. }\end{array}$ & 4.22 & .84 & $\begin{array}{c}\text { Strongly } \\
\text { Agree }\end{array}$ & 3.89 & .99 & Agree \\
\hline $\begin{array}{l}\text { I developed an emotional connection } \\
\text { with the cultural heritage site. }\end{array}$ & 4.10 & .86 & Agree & 3.68 & 1.07 & Agree \\
\hline Overall Mean & \multicolumn{2}{|c|}{4.13} & Agree & \multicolumn{2}{|c|}{3.80} & Agree \\
\hline
\end{tabular}

This result infers that visitors wanted to have a positive mood while touring the cultural heritage site. They wanted to feel and have an emotional connection with the past life in the site which will give them a feel of joy and pride. The evidence of visitors wanting connection with the past is congruent with the study of Schmitt [32] that affective interaction among the participants produced a connection that gave the site a sense of empathy. 
Table 7. Creative Cognitive Experiences (Think) at the Cultural Heritage Sites.

\begin{tabular}{|c|c|c|c|c|c|c|}
\hline \multirow[b]{2}{*}{$\begin{array}{c}\text { Creative Cognitive Experiences } \\
\text { (Think) }\end{array}$} & \multicolumn{3}{|c|}{ San Agustin Church $n=200$} & \multicolumn{3}{|c|}{ Malacañang of the North $n=185$} \\
\hline & Mean & SD & VI & Mean & SD & VI \\
\hline $\begin{array}{l}\text { The visit to the cultural heritage site } \\
\text { widened my knowledge and } \\
\text { understanding of history }\end{array}$ & 4.16 & .88 & Agree & 3.87 & 1.05 & Agree \\
\hline $\begin{array}{l}\text { I appreciated Philippine history and } \\
\text { culture more because of my visit. }\end{array}$ & 4.30 & .83 & $\begin{array}{l}\text { Strongly } \\
\text { Agree }\end{array}$ & 3.87 & 1.09 & Agree \\
\hline I appreciated the uniqueness of the site. & 4.40 & .80 & $\begin{array}{l}\text { Strongly } \\
\text { Agree }\end{array}$ & 3.99 & 1.01 & Agree \\
\hline $\begin{array}{l}\text { I learned the different cultures and } \\
\text { lifestyles during the period. }\end{array}$ & 4.11 & .93 & Agree & 3.74 & 1.05 & Agree \\
\hline $\begin{array}{l}\text { After the visit, my interest in history was } \\
\text { enhanced. }\end{array}$ & 4.12 & .94 & Agree & 3.70 & 1.15 & Agree \\
\hline $\begin{array}{l}\text { My curiosity about life and culture during } \\
\text { that period was satisfied. }\end{array}$ & 4.04 & .89 & Agree & 3.69 & 1.13 & Agree \\
\hline Overall Mean & \multicolumn{2}{|c|}{4.19} & Agree & \multicolumn{2}{|c|}{3.81} & Agree \\
\hline
\end{tabular}

Table 7 shows that most of the respondents agree that they appreciated the uniqueness of the site, receiving the highest mean score of 4.40 with standard deviation of 80 (San Agustin Church) and 3.99 with standard deviation of 1.01 (Malacañang of the North). This only means that both the sites offers a creative cognitive experiences to its visitors. The curiosity of the tourists about life and culture during that period were satisfied received the lowest mean of 4.04 and 3.69 respectively. This shows that the visitors' interest to know the past culture of the sites were partially satisfied. An overall mean of 4.19 and 3.81 was computed for San Agustin Church and Malacañang of the North respectively, which means, respondents agree that the cultural heritage sites offers creative cognitive experiences.

This result implies that visitors go to cultural heritage sites because they wanted to learn more about the history of the site. They wanted their curiosity to be satisfied and one way of doing it is to provide tour guide who will explain and discuss information about the cultural heritage site. This result was been consistent with the study of Musa et al. [35] that providing tour guide services will help improve the cognitive experience of the visitors. This result also supports the study of de Guzman, et al., [36] that acquisition of knowledge will satisfy the needs of Filipino adolescents as travelers.

Table 8. Physical Experiences (Act) at the Cultural Heritage Sites.

\begin{tabular}{|c|c|c|c|c|c|c|}
\hline \multirow{2}{*}{ Physical Experiences (Act) } & \multicolumn{3}{|c|}{ San Agustin Church $\mathbf{n}=\mathbf{2 0 0}$} & \multicolumn{3}{|c|}{ Malacañang of the North $n=185$} \\
\hline & Mean & SD & VI & Mean & SD & VI \\
\hline $\begin{array}{l}\text { It was convenient to move from one } \\
\text { place to another while inside the cultural } \\
\text { heritage site }\end{array}$ & 4.07 & .94 & Agree & 3.85 & 1.11 & Agree \\
\hline $\begin{array}{l}\text { Visiting the cultural heritage site gave } \\
\text { me the chance to do some physical } \\
\text { activity performed during the period. }\end{array}$ & 3.97 & .98 & Agree & 3.64 & 1.10 & Agree \\
\hline $\begin{array}{l}\text { There is a variety of things to do at the } \\
\text { cultural heritage site to let visitors } \\
\text { experience the way of life during the } \\
\text { period. }\end{array}$ & 4.04 & 1.00 & Agree & 3.74 & 1.09 & Agree \\
\hline Overall Mean & \multicolumn{2}{|c|}{4.03} & Agree & \multicolumn{2}{|c|}{3.74} & Agree \\
\hline
\end{tabular}

Table 8 shows that the respondents agreed that it was convenient to move from one place to another while inside the cultural heritage site with a mean score of 4.07 with standard 
deviation of 94 (San Agustin Church) and 3.85 with standard deviation of 1.10 (Malacañang of the North). This only portrays that the two cultural heritage sites have a wide space and can accommodate large number of visitors. Though there is a huge space where tourists can move from one place to another inside the cultural heritage sites, visitors rated the lowest that sites gave them the chance to do some physical activity performed during the period with a means score of 3.97 (San Agustin Church) and 3.64 (Malacañang of the North) which means that there were only few activities that can be done inside the sites. An overall mean of 4.03 and 3.74 was computed for San Agustin Church and Malacañang of the North respectively, meaning, respondents agree that there are physical involvements in the cultural heritage sites.

This result of the study implies that visitors wanted to participate actively in all the activities provided for them that are related to the culture of the site. Physical experiences can be enhanced when visitors are given enough space to roam around the cultural heritage site. Physical activities like picture taking and interacting to local people are some of the most evident physical activities that can be seen in the cultural heritage sites.

Table 9 shows that the respondents agreed that after their visit to the cultural heritage sites, they feel partially responsible in preserving the Filipino culture with the highest mean score of 4.25 and a standard deviation of 88 (San Agustin Church) and 3.95 and a standard deviation of 1.00 (Malacañang of the North). This means that the cultural heritage site made an impact to the social-identity of the visitors. In contrary, the personal/spiritual values were strengthened because of my visit to the site receives the lowest rating with a mean score of 3.93 and 3.56 respectively. An overall mean of 4.11 and 3.73 was computed for the overall social-identity experience in the cultural heritage sites, and the respondents answered agree.

Table 9. Social-identity Experiences (Relate) at the Cultural Heritage Sites.

\begin{tabular}{|c|c|c|c|c|c|c|}
\hline \multirow{2}{*}{ Social-identity Experiences (Relate) } & \multicolumn{3}{|c|}{ San Agustin Church n=200 } & \multicolumn{3}{|c|}{ Malacañang of the North $n=185$} \\
\hline & Mean & SD & VI & Mean & SD & VI \\
\hline $\begin{array}{l}\text { My personal/spiritual values were } \\
\text { strengthened because of my visit to the } \\
\text { site. }\end{array}$ & 3.93 & 1.06 & Agree & 3.56 & 1.14 & Agree \\
\hline $\begin{array}{l}\text { Visiting the cultural heritage site offered } \\
\text { a unique opportunity to understand the } \\
\text { local culture }\end{array}$ & 4.12 & .95 & Agree & 3.74 & 1.08 & Agree \\
\hline $\begin{array}{l}\text { The other visitors at the site made the } \\
\text { experience more meaningful and real. }\end{array}$ & 4.05 & 1.02 & Agree & 3.62 & 1.20 & Agree \\
\hline $\begin{array}{l}\text { The local people at the site made the } \\
\text { experience more meaningful and real. }\end{array}$ & 4.11 & .95 & Agree & 3.68 & 1.15 & Agree \\
\hline $\begin{array}{l}\text { I feel partially responsible in preserving } \\
\text { the Filipino culture after seeing the } \\
\text { cultural heritage site. }\end{array}$ & 4.25 & .88 & $\begin{array}{l}\text { Strongly } \\
\text { Agree }\end{array}$ & 3.95 & 1.00 & Agree \\
\hline $\begin{array}{l}\text { The visit to the site made me feel } \\
\text { connected with my ancestries. }\end{array}$ & 4.18 & .97 & Agree & 3.83 & 1.13 & Agree \\
\hline Overall Mean & 4.1 & & Agree & & & Agree \\
\hline
\end{tabular}

This result suggests that visitors tend to look for some meaning to their visit to the cultural heritage sites. Most of the time, they relate their history to the past life of the cultural heritage site which makes them connected with it. Understanding and preservation of the local culture are among the things that visitors do to enhance their social identity experience. This corresponds to the study of Musa et al. [35] that elements of animal protection and social interaction need a more mature life experience that is enjoyed most by visitors.

Experiences of visitors in a cultural heritage site involve their senses, feelings, thinking, actions and relations to anyone in the site. Visitors wanted to experience the cultural heritage site in an all-in manner. They wanted their physical, mental and spiritual body to be active 
during the visit. This was been supported by the study of Oh \& Jeoung [37] that tourist experience is all that tourists go through at a destination, and this may be behavioral or perceptive, cognitive or emotional, or articulated or inferred, and it is generated through the process of traveling, experiencing, studying, enjoying and living in different forms of life [38]. Experiences involve the entire person, and often result from direct observation and/or involvement in actual, dreamlike or virtual events [32]. To provide these aspects of experiences in a cultural heritage site will make the experience of the visitors complete and memorable. Managers of cultural heritage sites must be aware of these aspects of experience so as to give an overall satisfaction to the visitors.

\subsection{Relationship of Authenticity and Visitors' Experience}

To examine the relationship of authenticity and visitors' experience, Pearson $r$ correlation coefficient was conducted. Table 11 shows the result of the Pearson $r$. The foregoing analysis was performed in response to the objective of the study aiming to find the relationship between the authenticity and the visitors' experience.

Table 10. Pearson $r$ correlation coefficient between authenticity and visitors' experience

\begin{tabular}{lccc}
\hline & Visitors' Experience & P Value & Interpretation \\
\hline Authenticity & 0.89 & 0.01 & Significant \\
\hline
\end{tabular}

Table 10 shows that there is a significant relationship between authenticity and visitors' experience, $\mathrm{r}(385)=.89, \mathrm{p}>.01$. Higher level of authenticity is associated with the higher level of visitors' experience. In fact, majority of the visitors were educated (college level), they prefer a more authentic destination when traveling, they can also be considered as cultural tourist. Cultural tourists are more educated and value the local cultural and natural resources [39]. According to Stebbins [40], the key motivation of cultural tourists is to gam awareness of the area, to learn, explore and experience more about the destination visited [41]. So, when the visitors gain more knowledge about the site, they are visiting their experiences enhances.

The key implication of this research is that visitors' perceived authenticity on a cultural heritage site will have an effect on their experiences. Visitors develop a higher level of experience when there is a higher level of authenticity. The result of this study supported the claim of Expedia [34] research that tourists especially millennials from all over the world prioritize authenticity in their travel experience. Also, in the study of Harvey [42], he stated that visitors likely goes to destinations like park because they want to experience authenticity, feel authentic and have an experience conducive to learning and appreciation of the past. This also proves the claim of Cetin \& Bilgihan [43] that the tourist experience is influenced by initial and special local clues that are distinct from home and other destinations.

In relation to local authentic evidences, Urry [44]suggested gazing as an essential part of the tourist experience. As shown by him, the 'tourist gaze' is the selection and conversion of local ordinary artifacts, signs, places and experiences into sacred ones by tourists. Given that authenticity of a cultural heritage site is important in the tour experience of the visitors, managers of cultural heritage site should not totally alter authenticity just to gain a positive response from the visitors, rather, provide activities and look for attractions and sites that will really represent the culture and heritage of the area.

\subsection{Enhancement of Visitors' Experience in a Cultural Heritage Site}


The Visitors' Enhancement Program (VEEP) developed by the researcher was based on the result of this study. This can be considered and used by the management of the San Agustin Church and Malacañang of the North or any other cultural heritage sites as an additional option in improving the quality of experience of their visitors:

a) Visitor's Experience Enhancement Program (VEEP)

b) Proposal for Cultural Heritage Sites of Paoay Ilocos Norte

\section{General Objective}

This proposal is intended for two most visited cultural heritage sites in Paoay, Ilocos Norte - the San Agustin Church and Malacanang of the North. The main objective of this is to provide an evidence-based visitor's experience enhancement program in the aim of improving the province' tourism.

\section{a) San Agustin Church}

The San Agustin Church, built from 1694 to 1710, is the world's most notable example of earthquake baroque architecture, and is inscribed as a UNESCO World Heritage Site in 1993 as the premier baroque church built by local craftsmen in the Philippines. Half a century later, the huge coral stone bell tower was built and stands some distance from the church as a protection against damage during earthquakes. The buttresses adorned with with scroll motifs are its most recognizable feature. It is also declared as a National Cultural Treasure and a National Historical Landmark.

\section{b) Malacañang of the North}

Malacañang of the North, also known as Malacañang ti Amianan, was a birthday gift from the former Philippine First Lady, Imelda Marcos, to the sixtieth birthday of her husband. It is among the family's assets which the Philippine government sequestered when President Marcos was removed from power. It was eventually returned back to the care of the Provincial Government of Ilocos Norte after 20 years under government control. Following the Governor's restorations and improvements, it was opened to the public as a museum on 1 January 2011.

Table 11. VEEP Proposal 1

\begin{tabular}{|c|c|c|}
\hline Project Title & \multicolumn{2}{|c|}{ Pangrikna (Sense) } \\
\hline $\begin{array}{l}\text { Cultural } \\
\text { Heritage Site }\end{array}$ & San Agustin Church & Malacañang of the North \\
\hline $\begin{array}{l}\text { Target Area of } \\
\text { Improvement }\end{array}$ & Sensory Experience & \\
\hline Type: & Exhibit/Business & \\
\hline $\begin{array}{l}\text { Target } \\
\text { Participants: }\end{array}$ & Local tourism officers, local businesses, cultural site & lanagers \\
\hline Objective: & $\begin{array}{l}\text { To enhance the experience of the visitors by utiliz } \\
\text { heritage site. }\end{array}$ & ng all his senses during his tour inside the cultural \\
\hline $\begin{array}{l}\text { Source } \\
\text { Funding: }\end{array}$ & Local Government Unit (LGU), Local businesses & \\
\hline $\begin{array}{l}\text { Proposed } \\
\text { Activities: }\end{array}$ & $\begin{array}{l}\text { a. Creating additional museum where materials } \\
\text { used to build the church are displayed. (LGU) } \\
\text { b. Providing a distinct smell while inside the } \\
\text { church thru burning of incense. (Site } \\
\text { Management) }\end{array}$ & $\begin{array}{l}\text { d. Providing a distinct smell while inside the } \\
\text { house like the smell of old wood or wax. (Site } \\
\text { Management) } \\
\text { e. Establishing local restaurants within the } \\
\text { surroundings of the cultural heritage site that }\end{array}$ \\
\hline
\end{tabular}




\begin{tabular}{lllll}
\hline Project Title & \multicolumn{5}{c}{ Pangrikna (Sense) } \\
\hline c. & $\begin{array}{l}\text { Establishing local restaurants within the } \\
\text { surroundings of the cultural heritage site that } \\
\text { will offer authentic local cuisine. (Local } \\
\text { businesses) }\end{array}$ & $\begin{array}{l}\text { will offer authentic local cuisine. (Local } \\
\text { business) }\end{array}$ & \\
\hline
\end{tabular}

Table 11 shows the different activities that INTO or MTO of Paoay can use to target and improved the experiences of the visitors focusing on their senses. Ilocano word "Pangrikna" was used as a title for this proposal as this represents the sense of a human being.

Table 12. VEEP Proposal 2

\begin{tabular}{|c|c|c|}
\hline \multirow{2}{*}{$\begin{array}{l}\text { Project Title } \\
\text { Cultural } \\
\text { Heritage Site }\end{array}$} & \multicolumn{2}{|c|}{ Pangderrep (Feel) } \\
\hline & San Agustin Church & Malacañang of the North \\
\hline $\begin{array}{l}\text { Target Area } \\
\text { of } \\
\text { Improvement }\end{array}$ & Affective Experience & \\
\hline Type: & Exhibit/Fair & Exhibit \\
\hline $\begin{array}{l}\text { Target } \\
\text { Participants: }\end{array}$ & $\begin{array}{l}\text { local security personnel, local government } \\
\text { unit }\end{array}$ & local government unit, local people \\
\hline Objective: & $\begin{array}{l}\text { To enhance the experience of the visitors } \\
\text { where they would feel the safety and } \\
\text { security and the way of life during the } \\
\text { Spanish period. }\end{array}$ & $\begin{array}{l}\text { To enhance the emotional connection of the } \\
\text { visitors to the cultural heritage site. }\end{array}$ \\
\hline $\begin{array}{l}\text { Source of } \\
\text { Funding: }\end{array}$ & Local Government Unit (LGU) & \\
\hline $\begin{array}{l}\text { Proposed } \\
\text { Activities: }\end{array}$ & $\begin{array}{l}\text { f. Increase the number of security personnel } \\
\text { wearing Spanish costume within the } \\
\text { vicinity of the area. } \\
\text { g. Selling of authentic products in Paseo de } \\
\text { Paoay or allotted area as a medium to } \\
\text { enhance and increase the interaction of } \\
\text { the local people and visitors. }\end{array}$ & $\begin{array}{l}\text { h. Selling of authentic products in allotted area } \\
\text { within the surroundings of the house as a } \\
\text { medium to enhance and increase the } \\
\text { interaction of the local people and visitors. } \\
\text { i. Showcase cultural performances like role } \\
\text { plays regarding the life of President Marcos. }\end{array}$ \\
\hline
\end{tabular}

Table 12 presents the second proposal of the VEEP focusing on the Affective Experience of the visitors. Pangderrep is the title of this proposal that came from the Ilocano word "derrep" meaning feelings.

Table 13. VEEP Proposal 3

\begin{tabular}{|c|c|}
\hline Project Title & Pangsirib (Think) \\
\hline $\begin{array}{l}\text { Cultural } \\
\text { Heritage Site }\end{array}$ & Malacañang of the North \\
\hline $\begin{array}{l}\text { Target Area } \\
\text { of } \\
\text { Improvement }\end{array}$ & Creative-Cognitive \\
\hline Type: & Seminar/Training \\
\hline $\begin{array}{l}\text { Target } \\
\text { Participants: }\end{array}$ & Tourist Guides, vendors and tricycle drivers around the vicinity \\
\hline Objective: & $\begin{array}{l}\text { Increase the knowledge of the locals specifically tourist guides, vendors and tricycle drivers } \\
\text { around the vicinity about the site's history and equip them with skills on how to integrate it in } \\
\text { dealing with tourists. }\end{array}$ \\
\hline $\begin{array}{l}\text { Source of } \\
\text { Funding: }\end{array}$ & Ilocos Norte Tourism Office, Local Government Unit \\
\hline $\begin{array}{l}\text { Proposed } \\
\text { Activities: }\end{array}$ & $\begin{array}{l}\text { j. Seminar/Workshop } \\
\text { A series of lectures/workshop on the following topics: } \\
\text { 1.Local History highlighting the San Agustin Church/Malacañang of the North } \\
\text { 2.Local culture and traditions } \\
\text { 3. Basic Principles in customer service/ tour guiding }\end{array}$ \\
\hline
\end{tabular}


Table 13 shows the proposed activities that can used by the INTO and MTO of Paoay focusing on the Creative-Cognitive. Since the objective of this proposal is to increase the knowledge of the locals, activities like seminars and workshop are being proposed to enhance their knowledge about the sites and improve their skills like communication and customer service. By, doing so they can give more reliable and credible information to visitors which can improve their experiences. The word pangsirib came from the root word sirib which means intelligent or wise.

Table 14. VEEP Proposal 4

\begin{tabular}{|c|c|c|}
\hline Project Title & \multicolumn{2}{|c|}{ Panggunay (Act) } \\
\hline $\begin{array}{l}\text { Cultural } \\
\text { Heritage Site }\end{array}$ & San Agustin Church & Malacañang of the North \\
\hline $\begin{array}{l}\text { Target Area } \\
\text { of } \\
\text { Improvement }\end{array}$ & Physical Experience & \\
\hline Type: & Exhibit/ Bazaar & \\
\hline $\begin{array}{l}\text { Target } \\
\text { Participants: }\end{array}$ & Local artists, small enterprises & \\
\hline Objective: & $\begin{array}{l}\text { Provide activities that will allow visitors exp } \\
\text { exhibits and let them enjoy local products of }\end{array}$ & $\begin{array}{l}\text { arience the way of life during the period through } \\
\text { he province }\end{array}$ \\
\hline $\begin{array}{l}\text { Source } \quad \text { of } \\
\text { Funding: }\end{array}$ & Local Government, Local Tourism Office, $\mathrm{Si}$ & e Management \\
\hline $\begin{array}{l}\text { Proposed } \\
\text { Activities: }\end{array}$ & $\begin{array}{l}\text { k. Showcase the creation of local artists } \\
\text { in exhibit. } \\
\text { 1. Abel making } \\
\text { m. Spanish dresses that tourist can try on } \\
\text { can be introduced }\end{array}$ & $\begin{array}{l}\text { n. Showcase the creation of local artists in } \\
\text { exhibit. } \\
\text { o. Abel making } \\
\text { p. Wearing of Filipiniana costumes like the } \\
\text { ones worn by Imelda Marcos while } \\
\text { touring inside the site can be introduced. }\end{array}$ \\
\hline
\end{tabular}

Table 14 shows the proposed activities that can be used by the INTO and MTO of Paoay to improve the Physical Experience of the visitors. This activities can also promote the different products of the province. Panggunay meaning physical movement.

Table 15. VEEP Proposal 5

\begin{tabular}{|c|c|c|}
\hline Project Title & \multicolumn{2}{|c|}{ Pakailasinan (Social-identity) } \\
\hline $\begin{array}{l}\text { Cultural } \\
\text { Heritage Site }\end{array}$ & San Agustin Church & Malacañang of the North \\
\hline $\begin{array}{l}\text { Target Area } \\
\text { of } \\
\text { Improvement }\end{array}$ & Social-identity Experience & \\
\hline Type: & Exhibit & \\
\hline $\begin{array}{l}\text { Target } \\
\text { Participants. }\end{array}$ & Local Artists, Tour Guides & \\
\hline Objective: & $\begin{array}{l}\text { To provide activities where visitors can } \\
\text { enhance their spiritual values and also will } \\
\text { strengthen their appreciation of } \\
\text { Filipino/Ilocano culture. }\end{array}$ & $\begin{array}{l}\text { To provide activities where visitors can } \\
\text { enhance their spiritual values and also will } \\
\text { strengthen their appreciation of } \\
\text { Filipino/Ilocano culture. }\end{array}$ \\
\hline $\begin{array}{l}\text { Source of } \\
\text { Funding. }\end{array}$ & Local Government, Local Tourism Office, Site & Management \\
\hline $\begin{array}{l}\text { Proposed } \\
\text { Activities: }\end{array}$ & $\begin{array}{l}\text { q. Showcase the creation of local artists in } \\
\text { exhibit. } \\
\text { r. Tour guides should discuss and } \\
\text { emphasize more the sacrifices of the } \\
\text { Ilocano people just to build the church } \\
\text { and importance of this structure in the } \\
\text { pride and identity of the Ilocanos. }\end{array}$ & $\begin{array}{l}\text { s. Showcase the creation of local artists } \\
\text { in exhibit. } \\
\text { t. Tour guides should discuss and } \\
\text { emphasize more the achievements of } \\
\text { President Marcos and the importance } \\
\text { of his achievements on the pride and } \\
\text { identity of the Ilocanos. }\end{array}$ \\
\hline
\end{tabular}


Table 15 presents the fifth and the last proposal of the VEEP focusing on the Socialidentity Experience of the visitors. Pakailasinan is the title of this proposal which means identity.

\section{c) Evaluation of Visitor's Experience Enhancement Program (VEEP)}

To check the effectivity of the proposed program (VEEP), it can be evaluated using the Perceived Authenticity and Visitor's Experience Survey Questionnaire instrument developed by the researcher. This can help the management of the cultural heritage site in measuring the perceived authenticity and experience of the visitors. The result of this study can be used as a basis for a comparative study in the future.

\section{Conclusion}

The tourism industry of Paoay, Ilocos Norte is growing and cooperative actions from the local government, private sector and locals are being done to up keep and accommodate the increasing number of tourist. There are existing tourism plans and programs in the municipality of Paoay, Ilocos Norte including marketing programs, economic, physical infrastructure and socio-cultural plans and programs for both the visitors and local people.

The visitors perceived that the design of the San Agustin Church and Malacañang of the North represents the architectural style of their period. As the former clearly portrayed the Spanish cultures and the latter portrayed the Filipino culture. The authenticity of the local natural surroundings of the two sites also added to the experience of the visitors. Visitors' experiences engages their senses most especially their sense of sight. The visit to the site allow them also to move conveniently from one place to another. Furthermore, the visitors consider their visit in these cultural heritage sites as a positive experience and that these visits made them feel that they are partially responsible in preserving Filipino culture.

This study also confirms that perceived authenticity of cultural heritage site is positively related to visitors' experience. This is important as this could become a foundation on how the different sectors of the tourism industry or service providers can enhance the experiences of their visitors.

\section{References}

[1] Gezici, F., \& Kerimoglu, E. (2010). Culture, tourism and regeneration process in Istanbul. International Journal of Culture, Tourism and Hospitality Research, 4(3), 252-265. https://doi.org/10.1108/17506181011067637

[2] Santagata, W., 2002. Cultural districts, property rights and sustainable economic growth. International Journal of Urban and Regional Research, 26(1), pp. 9-23.

[3] Abankina, T. (2013). Regional development models using cultural heritage resources. International Journal of Culture, Tourism and Hospitality Research, 7(1), 3-10. https://doi.org/10.1108/17506181311301318

[4] Correia, A., Kozak, M., \& Ferradeira, J. (2013). From tourist motivations to tourist satisfaction. International Journal of Culture, Tourism and Hospitality Research, 7(4), 411-424. https://doi.org/10.1108/IJCTHR-05-2012-0022

[5] Wan, P. Y. K., \& Cheng, E. I. M. (2011). Service quality of Macao's world heritage 
site. International Journal of Culture, Tourism and Hospitality Research, 5(1), 57-68. https://doi.org/10.1108/17506181111111762

[6] Boukas, N. (2012). "Young faces in old places": perceptions of young cultural visitors for the archaeological site of Delphi. Journal of Cultural Heritage Management and Sustainable Development, 2, 164-189. https://doi.org/10.1108/20441261211273653

[7] Mitsche, N., Vogt, F., Knox, D., Cooper, I., Lombardi, P., \& Ciaffi, D. (2013). Intangibles: enhancing access to cities' cultural heritage through interpretation. International Journal of Culture, Tourism and Hospitality Research, 7(1), 68-77. https://doi.org/10.1108/17506181311301381

[8] Di, L., Roberta, P., Mugion, G., Mattia, G., \& Renzi, M. F. (2015). Cultutal Heritage and Consumer Behavior: A survey on Italian cultural visitors. Journal of Cultural Heritage Management and Sustainable Development, 5(1), 61-81. https://doi.org/10.1108/JCHMSD-03-2013-0009

[9] Isaac, R. K., \& Cakmak, E. (2016). Understanding the motivations and emotions of visitors at Tuol Sleng Genocide Prison Museum ( S-21 ) in Phnom Penh, Cambodia. International Journal of Tourism Cities, 2(3), 232-247. https://doi.org/10.1108/IJTC06-2016-0014

[10] Koo, C., Chung, N., Kim, D. J., \& Hlee, S. (2016). The impact of destination websites and cultural exposure: a comparison study of experienced and inexperienced travelers. International Journal of Tourism Cities, 2(1), 1-16. https://doi.org/10.1108/IJTC-042015-0009

[11] Nassar, M. a., Mostafa, M. M., \& Reisinger, Y. (2015). Factors influencing travel to Islamic destinations: an empirical analysis of Kuwaiti nationals. International Journal of Culture, Tourism and Hospitality Research, 9(1), 36-53.

https://doi.org/10.1108/IJCTHR-10-2014-0088

[12] Bordoni, L. (2011). Technologies to support cultural tourism for Latin Latium. Journal of Hospitality and Tourism Technology, 2(2), 96-104. https://doi.org/10.1108/17579881111154218

[13] Mehrhoff, W. A., 1998. Cultural tourism. In: N. L. Shumsky, ed. Encyclopedia of Urban America: The Cities and Suburbs. Santa Barbara, CA: ABC-CLIO.

[14] Chhabra, D., Healy, R. \& Sills, E., 2003. Staged authenticity and heritage tourism. Annals of Tourism Research, 30(3), p. 702-719.

[15] Chhabra, D. (2010). Back to the past: a sub-segment of Generation Y's perceptions of authenticity. Journal of Sustainable Tourism, 18(6), 793-809. https://doi.org/10.1080/09669582.2010.483280

[16] Cho, M. (2012). A Study of Authenticity in Traditional Korean Folk Villages, (Cho, M. (2012). A Study of Authenticity in Traditional Korean Folk Villages, (2004103), 145171. https://doi.org/10.1080/152564809032002392004103), 145-171. https://doi.org/10.1080/15256480903200239

[17] Yang, L., \& Wall, G. (2009). Authenticity in ethnic tourism : domestic tourists ' perspectives, 12(3), 235-254. https://doi.org/10.1080/13683500802406880

[18] Timothy, D. J., \& Prideaux, B. (2004). Issues in Heritage and Culture in the Asia Pacific Region, 9(3).

[19] Shen, S., Guo, J., \& Wu, Y. (2014). Investigating the Structural Relationships among Authenticity, Loyalty, Involvement, and Attitude toward World Cultural Heritage Sites : An Empirical Study of Nanjing Xiaoling Tomb, China, 19(1), 103-121.

[20] Halewood, C., \& Hannam, K. (2001). Viking heritage tourism: authenticity and commodification. Annals of Tourism Research, 565-80. 
[21] Smith, M. (2003). Issues in Cultural Tourism Studies. London: Routledge.

[22] Condevaux, A. (2009). ori Culture on Stage : Authenticity M a and Identity in Tourist Interactions 1, 19(2), 143-161. https://doi.org/10.1080/00664670902980389

[23] Kolar, T., \& Zabkar, V. (2007). The meaning of tourists' authentic experiences for the marketing of cultural heritage sites. Economic Business Review, 235-56.

[24] Wang, N. (1999). Rethinking authenticity in tourism. Annals of Tourism Research, 26, 349-370.

[25] Knudsen, B. T., \& Waade, A. M. (2010). Re-investing authenticity: Tourism, place and emotions.

[26] Top Philippine World Heritage Sites. (2009). Retrieved from It's More Fun in the Philippines: http://www.tourism.gov.ph/sitepages/top10sitetogo.aspx

[27] Ruiz, A.-X. (2017, December 29). (R. M. Oasay, Interviewer)

[28] TripAdvisor. (2018). Top 10 Things to do in Ilocos Norte Province. Retrieved from TripAdvisor: https://www.tripadvisor.com.ph/Attractions-g1486578-ActivitiesIlocos_Norte_Province_Ilocos_Region_Luzon.html\#ATTRACTION_SORT_WRAPP ER

[29] Lazaro, F. G. (2016, April 07). Ilocos Norte breaks record on Holy Week tourist arrival. Retrieved from Philippine Information Agency (PIA):

http://news.pia.gov.ph/article/view/381459805044/ilocos-norte-breaks-record-on-holyweek-tourist-arrival

[30] Castro, M. G. (2017, April 27). Ilocos Norte posts 6\% increase in Holy Week tourist arrivals, $103 \%$ in two years. Retrieved from Provincial Government of Ilocos Norte: http://inorte.org/news/ilocos-norte-posts-6-increase-in-holy-week-tourist-arrivals-103in-two-years

[31] Palma, R. A. (2013, June 26). Malacanang of the North. Retrieved from Choose Philippines: http://www.choosephilippines.com/go/heritage-sites/314/Malacanang-ofthe-North

[32] Schmitt, B. (1999). Experiential marketing. Journal of Marketing Management, Vol. 15 (Nos 1-3), 53-67.

[33] MacCannell, D. (1973). Staged authenticity: arrangements of social space in tourist settings. American Journal of Sociology, 589-603.

[34] Expedia. (2016). Millennial Traveller Report.

[35] Musa, G., Mohammad, I., Thirumoorthi, T., Moghavvemi, S., \& Kasim, A. (2015). Exploring visitors' experience using strategic experiential modules (SEMs): the case of Zoo Negara, Kuala Lumpur. International Journal of Tourism Cities, 1(3), 234-253. https://doi.org/10.1108/IJTC-08-2014-0012

[36] de Guzman, A. B., de Castro, B. V., Bernardo, J., Ladra, M. ,., Tiburcio, R., \& Villanueva, A. (2015). Filipino adolescents' preferences, familiarity level and attitudinal dispositions for heritage sites visits. Asian Journal of Tourism and Hospitality Research, 8 and 9(1). Retrieved from http://ejournals.ph/form/cite.php?id=10484

[37] Oh, H. F., \& Jeoung, M. (2007). Measuring experience economy concepts: tourism applications. Journal of Travel Research.

[38] Stamboulis, Y., \& Skayannis, P. (2003). Innovation strategies and technology for experience-based tourism. Tourism Management.

[39] Hughes, H. (1987). Culture as a tourist resource: A theoretical consideration. Tourism Management, 8(3), 205-216. 
[40] Stebbins, R. A. (1996). Cultural tourism as a serious leisure. Annals of Tourism Research, 948-950.

[41] Richards, G., 2002. Tourism attraction systems: Exploring cultural behavior. Annals of Tourism Research, p. 1048-1064.

[42] Harvey, W. R. (2004). Authenticity and Experience among Visitors at a Historic Village. Retrieved from http://scholar.lib.vt.edu/theses/available/etd-03052004-132332/

[43] Cetin, G., \& Bilgihan, A. (2016). Components of cultural tourists' experiences in destinations. Current Issues in Tourism, 19(2), 137-154.

[44] Richards, G. (2002). Tourism attraction systems: Exploring cultural behavior. Annals of Tourism Research, 1048-1064.

[45] Urry, J. (1990). The tourist gaze. Sage. 